\title{
Kearifan Lokal dan Pemberantasan Korupsi dalam Birokrasi
}

\author{
IRAWATI \\ Jurusan IImu Politik, Fakultas IImu Sosial dan IImu Politik, Universitas Andalas, \\ Kampus Unand Limau Manis, Padang PO BOX 166, Indonesia \\ email: ira.tanjung@gmail.com
}

\begin{abstract}
One thing that considered as a source of systemic and networking corruption in Indonesia is bureaucratic behavior with patrimonial relations approach. Source of bureaucratic pathology essentially can be identified from two locus: internal and external. This paper attempts to explain other possibility to eradicate corruption in bureaucracy by strengthening external environment role. Using qualitative research data in Nagari Kapau of West Sumatra, indicating that culture became one of important strategy to eradicating corruption in bureaucracy. Culture values support the emergence of social structure as a controller of Nagari bureaucratic work. Cultural values are followed by society awareness and participation of their role in overseeing leader and government to become power that be able to power-driven corruption.
\end{abstract}

Keyword: local wisdom, corruption, Bureaucracy and local society

\begin{abstract}
Abstrak. Satu hal yang dianggap menjadi sumber betapa sistemik praktik korupsi di Indonesia adalah perilaku birokrasi dengan pendekatan relasi patrimonialistik. Sumber penyakit birokrasi dapat diidentifikasi dari dua lokus: internal dan eksternal. Tulisan ini melihat peluang lain pemberantasan korupsi dalam birokrasi dengan penguatan peran lingkungan eksternal. Dengan belajar dari pengalaman nagari Kapau propinsi Sumatera Barat, menunjukkan bahwa budaya masyarakat menjadi salah satu kekuatan penting bagi strategi pemberantasan korupsi di birokrasi. Nilai-nilai kultural mendukung munculnya struktur masyarakat sebagai pengontrol kerja birokrasi Nagari. Nilai-nilai kultural ini di ikuti oleh kesadaran dan partisipasi masyarakat akan peran mereka dalam mengawasi pemimpin dan pemerintahan sehingga menjadi kekuatan yang dapat men-driven pemberantasan korupsi.
\end{abstract}

Kata kunci: Kearifan Lokal, Korupsi, Birokrasi dan Masyarakat Lokal

\section{Pendahuluan}

Korupsi dan penyelenggaraan negara merupakan dua hal yang memang sulit untuk dipisahkan. Kasus-kasus korupsi besar yang berhasil diungkap oleh KPK dan lembaga lain, memperlihatkan betapa kasus korupsi memang sudah sangat menggurita dan sistemik di Negara ini. Keterlibatan pejabat publik dan birokrasi menjadi suatu keniscayaan, tidak hanya pada level pusat tetapi juga mengakar hingga level daerah hingga unit terkecil dari birokrasi seperti Kelurahan/ desa. Kasus penahanan pejabat daerah atas tindakan korupsi menjadi santapan biasa bagi publik. Meskipun upaya pemberantasan korupsi terus digencarkan, bahkan melalui upaya luar biasa sekalipun -pembentukan KPK dan Pengadilan Tindak Pidana Korupsi-, namun sepertinya kerja pemberantasan korupsi masih belum mampu menguranginya, mengingat begitu sistemik dan meluasnya praktik korupsi.

Tidak hanya upaya pemberantasan, upaya pencegahan pun sebenarnya telah dilakukan oleh Pemerintah melalui pengaturan kelembagaan pemerintahan dengan berbagai peraturan dan mekanisme yang diangap mampu mencegah perilaku korup. Tetapi apa daya, perilaku korup seperti menemukan banyak jalan untuk tetap tumbuh subur dan makin sistemik. Satu hal yang ditengarai menjadi sumber betapa sistemik dan berjejaringnya praktik korupsi di Indonesia, ialah warisan birokrasi masa lalu, yang lebih mengedepankan pada pendekatan relasi patrimonialistik.

Reformasi birokrasi yang digulirkan pemerintah semenjak tahun 2001 ternyata tetap belum mampu memperbaiki budaya birokrasi. Meskipun berbagai model reformasi birokrasi yang dirancang oleh para intelektual dan pemerintah 
hanya memiliki sedikit kemampuan untuk menekan perilaku birokrasi yang cenderung korup. Dengan kata lain reformasi dari internal birokrasi saja belum efektif dalam memberantas korupsi. Dalam kondisi seperti ini perlu dikembangkan strategi baru memberantas korupsi dalam birokrasi.

Sumber penyakit birokrasi pada dasarnya dapat diidentifikasi dari dua lokus: internal dan eksternal. Sumber internal berasal dari kelemahan dan kegagalan sistem yang ada di birokrasi itu sendiri. Secara internal, timbulnya perilaku korup dalam birokrasi juga disebabkan lemahnya sistem pengawasan internal. Sistem pengawasan atasanbawahan praktis tak mungkin terjadi dalam sistem yang korup secara bersama-sama. Penyakit inilah yang menjadi fokus dari reformasi birokrasi yang dilaksanakan pemerintahan sejak satu dekade yang lalu, meskipun belum mencapai hasil yang diharapkan.

Secara eksternal, penyakit korupsi dalam birokrasi bisa disebabkan oleh relasi antar berbagai sistem yang terkait, misalnya kooptasi dan intervensi politik. Dalam banyak kasus korupsi birokrasi di daerah, tekanan politik menjadi salah satu sumber penyebab. Hal ini bermula dari proses pengisian jabatan yang sangat tertutup dan berbasis hubungan afiliasi. Faktor eksternal lain adalah budaya masyarakat yang sangat permisif dan menjadikan suap / gratifikasi dalam proses pemerintahan dan pelayanan sebagai hal yang biasa. Artinya, terjadi penawaran dan permintaan antara birokrasi dan masyarakat untuk sebuah pelayanan. Kesadaran masyarakat untuk mengawasi perilaku birokrasi juga cenderung apatis, meskipun secara kasat mata mereka menyadari akan perilaku korupsi birokrat. Budaya masyarakat sebagai bagian dari lingkungan birokrasi menjadi salah satu pendukung penting bagi perbaikan perilaku dan budaya birokrasi itu sendiri. Reformasi dari lingkungan eksternal juga diperlukan bagi dukungan pemberantasan korupsi.

Tulisan ini mencoba melihat peluang lain pemberantasan korupsi dalam birokrasi dengan penguatan peran lingkungan eksternal. Tulisan ini merupakan hasil penelitian yang dilakukan di Nagari Kapau Kabupaten Agam Propinsi Sumatera Barat dengan menggunakan metode penelitian kualitatif. Temuan memperlihatkan bahwa budaya masyarakat menjadi salah satu dasar penting bagi strategi pemberantasan korupsi dengan belajar pada kasus kekuatan budaya masyarakat Nagari Kapau propinsi Sumatera Barat yang mampu memberantas korupsi di birokrasi.

\section{Wajah Birokrasi dengan Warisan Budaya Masa Lalu}

Wajah birokrasi Indonesia tidak lepas dari sejarah birokrasi masa lalu yang memiliki citra buruk, khususnya semasa Orde Baru yang menjadikan birokrasi sebagai mesin politik. Imbas dari itu semua, masyarakat harus membayar biaya yang mahal untuk mendapatkan layanan, ketidakpastian waktu, ketidakpastian biaya, dan ketidakpastian siapa yang bertanggung jawab adalah beberapa fakta empiris yang menunjukkan rusaknya layanan birokrasi. Lebih dari itu, layanan birokrasi justru menjadi salah satu causa prima terhadap maraknya korupsi, kolusi, nepotisme. Pejabat politik yang mengisi birokrasi pemerintah sangat dominan. Kondisi ini cukup lama terbangun sehingga membentuk sikap, perilaku, dan opini bahwa pejabat politik dan pejabat birokrat tidak dapat dibedakan.

Peluang pejabat politik yang besar untuk mengatur dan mengambil alih birokrasi, ditengarai menjadi sumber betapa sistemik dan berjejaringnya praktik korupsi di Indonesia dengan lebih mengedepankan pada pendekatan relasi patrimonialistik (Djafar, 2006: 5). Melalui relasi ini, para birokrat-pejabat negara, pegawai pemerintah, kaum pengusaha, dan aparat penegak hukum, bertemu membentuk jejaring korupsi, yang memberi untung bagi mereka dalam sebuah hubungan patron dan klien. Mochtar Lubis menjelaskan segenap akar tindakan korupsi yang terjadi di Indonesia adalah birokrasi yang patrimonial. Menurut Lubis, negara birokrasi patrimonial adalah lingkungan terbaik bagi tumbuh suburnya korupsi (Lubis dalam Semma, 2008). Dalam konteks birokrasi, Weber memberikan penilaian bahwa sistem birokrasi patrimonial, ialah suatu sistem birokrasi dimana jabatan dan perilaku dalam keseluruhan hirarki birokrasi lebih didasarkan pada hubungan familier, hubungan pribadi dan hubungan 'bapak-anak buah' (patron client) (Weber dalam Muhaimin, 1980:21).

Etzioni dan Halevy mendefinisikan birokrasi sebagai organisasi hirarkis pemerintah yang ditunjuk untuk menjalankan tugas melayani kepentingan umum (Etzioni et.al., 1983: 1). Menurut Etzioni dan Halevy idealnya birokrasi bersikap netral sekaligus patuh, hanya bertanggung jawab pada pekerjaan yang diurusi dan sekaligus tunduk pada tanggung jawab yang sudah digariskan oleh organisasi/unit kerja masingmasing. Pada kenyataannya menunjukkan eksistensi birokrasi yang sejak awal berdiri dalam struktur politik yang kerap membuatnya berada dalam situasi dilematis. Dilema paling awal adalah posisi birokrasi, seperti antara instrumen negara dan menjaga independensi; antara implementor dan formulator kebijakan; antara kekuatan politis dan kekuatan administratif.

Posisi ini membuat birokrasi seringkali ambigu. Potensi birokrasi untuk tumbuh hanya memenuhi kepentingan dirinya merasionalisasikan kebutuhan pentingnya kontrol politisi terhadap 
birokrasi, namun pada saat bersamaan, agar dapat bekerja menurut standar-standar profesionalisme (adil dan imparsial) maka birokrasi juga dituntut untuk terbebas dari intervensi politik. Intinya birokrasi pada saat yang bersamaan, birokrasi dan para birokrat, harus bersikap politis dan non politis sekaligus (Etzioni et.al., 1983:92). Dilema ini yang dialami birokrasi Indonesia pada masa lalu, yang membuat birokrasi dikalahkan oleh kepentingan politis dan menjadikanya sebagai alat untuk memperbesar kekuasaan dengan membangun budaya relasi patron klien (birokrasi patrimonial).

Selain pengaruh dari sistem birokrasi patrimonial, kekuasaan absolut birokrasi juga semakin berkembang karena konsepsi negara modern yang mempunyai kapasitas untuk memonitor ekonomi rakyatnya dan kemampuannya untuk menyediakan pelayanan publik (Maclver, 1977). Konsepsi negara modern selanjutnya meningkat kapasitasnya menjadi sistem negara kesejahteraan (welfare state), yang mengharuskan birokrasi untuk kuat dalam menjalankan peran-peran tersebut. Birokrasi dalam negara modern menjadi aktor yang memberikan alokasi bagi sumberdaya yang terus bertambah. Akibatnya, semakin banyak orang yang menggantungkan hidupnya pada birokrasi, demi menjamin kelangsungan hidupnya (Hadiz et.al., 2006: 10).

Legitimasi rezim orde baru yang mengembangkan orientasi negara dengan slogan pembangunan, menciptakan para birokrat yang menjalin kedekatan dengan penguasa. Korupsi banyak dilakukan dengan menggunakan kedok birokrasi, seperti badan pengawas keuangan, I rjen di tiap departemen, parlemen, dan kejaksaan (Semma, 2008). Parahnya lagi jejaring korupsi yang sistemik, dan para koruptor dalam jalur-jalur birokrasi berusaha melindungi tindakannya dengan berbagai macam teori, dan meligitimasinya dengan berbagai aturan hukum. Pada titik inilah birokrasi menjadi sumber terjadinya tindakan korupsi yang dilakukan oleh para birokrat, atau orang yang menggantungkan hidupnya pada birokrasi. Kewenangan besar dimiliki birokrat sehingga hampir semua aspek kehidupan masyarakat ditangani birokrasi. Kewenangan yang terlalu besar itu bahkan akhirnya menonjolkan peran birokrasi sebagai pembuat kebijakan ketimbang pelaksana kebijakan, lebih bersifat menguasai daripada melayani masyarakat. Akhirnya, wajar saja jika kemudian birokrasi lebih dianggap sebagai sumber masalah atau beban masyarakat ketimbang sumber solusi bagi masalah yang dihadapi masyarakat. Budaya korupsi yang dengan model birokrasi patrimonial membuat penyakit akut dalam birokrasinya Indonesia.

Melihat fenomena yang berkembang di In- donesia, korupsi telah memiliki struktur dan menjadi kultur dan membentuk jaringan sistemik yang sangat kuat dalam lingkaran birokrasi Indonesia. Sistem birokrasi yang seharusnya memberikan dukungan utama dalam suatu negara modern, justru pada praktiknya banyak menjadi sumber masalah, yang menjadi penghambat dalam penyelenggaraan sistem negara. Birokrasi yang dibangun oleh pemerintah sebelum era reformasi telah membangun budaya birokrasi yang kental dengan Korupsi, Kolusi, dan Nepotisme (KKN). Model birokrasi dengan budaya menguasai bukan melayani dan jejaring korupsi yang sistemik ini, dalam era reformasi menjadi tantangan untuk melakukan reformasi birokrasi. Isu reformasi birokrasi mendapat perhatian yang besar dari pemerintahan pasca reformasi, baik masa Habibie, Gus Dur dan presiden berikutnya. Berbagai kebijakan dikeluarkan pemerintah, untuk mendukung reformasi birokrasi tersebut. Pengaturan kelembagaan hingga pengembangan konsep good governance sering diartikan sebagai indikator terealisasikannya reformasi birokrasi dengan terpenuhinya prinsip-prinsip seperti, partisipasi masyarakat, tegaknya supremasi hukum, transparansi, kepedulian kepada stakeholder, berorientasi kepada konsensus, kesetaraan, efektifitas dan efisiensi, akuntabilitas, dan visi strategis.

Dalam program Pemerintahan Presiden Susilo Bambang Yudhoyono menekankan urgensi pemberantasan korupsi dan reformasi birokrasi. Kedua hal ini saling terkait erat, tidak mungkin dapat memberantas korupsi tanpa upaya reformasi birokrasi di internal pemerintahan. Restrukturisasi dan reposisi birokrasi Indonesia saat ini dapat dilakukan dengan mempertimbangkan kondisi perubahan sistem politik antara pemerintahan masa lalu dengan pemerintahan masa kini di era reformasi. Akan tetapi, kenyataanya pemerintahan pasca reformasi pun tidak mampu menjamin keberlangsungan reformasi birokrasi terealisasi dengan baik.

Tingginya tarik ulur kepentingan dan proses politik yang dipenuhi dengan mekanisme transaksional dalam setiap moment transisi, telah menyeret proses reformasi ke dalam pusaran kepentingan kelompok elit tertentu. Pembajakan(hijacking) atas konsolidasi kekuasaan ini khususnya dilakukan oleh kelompok status quopredatoris yang menghendaki bertahannya kekuasaan orde baru, dan kelompok-kelompok yang membawa kepentingan kuasa modal, yang menginginkan keuntungan sebesar-besar bagi kelompoknya (Robinson et.all, 2004).

Birokrasi sekarang sudah menjadi sarang terjadinya tindak pidana korupsi. Senjata macam apakah yang kemudian bisa digunakan untuk memberantasnya? Belajar dari teori yang diajarkan 
Weber tentang konsep idealitas, birokrasi sangat identik dengan pejabat dan jabatan, dalam sudut pandang sosiologi, pejabat merupakan tipe peranan sosial yang penting. Bahwa pejabat adalah seseorang yang memiliki tugas-tugas khusus dan fasilitas yang dimilikinya dalam melaksanakan jabatannya merupakan pemberian dari orang lain. Perbedaan antara pejabat dan kelas pekerja adalah terdapat pada otoritasnya, dalam melaksanakan tugas. Seorang pejabat memiliki otoritas jabatan, sedangkan pekerja hanya melaksanakan perintah majikan (Albrow, 2005: 34-40). Alatas kemudian berkeyakinan bahwa suatu masyarakat masih mempunyai peluang untuk keluar dari belenggu korupsi, apabila masih ada segelintir orang yang idealis dalam masyarakat. Akan tetapi keyakinan ini dibantah oleh Chambliss, dia melihat bahwa perubahan dari dalam masyarakat itu sendiri, akan mengalami jalan buntu jika korupsi sudah membentuk suatu jejaring yang melibatkan berbagai unsur masyarakat (Aditjondro, 2002:20).

\section{Arah Reformasi Birokrasi}

Melihat rumit dan sistemiknya jejaring korupsi yang ada sekarang, maka diperlukan satu usaha bersama baik yang sifatnya lokal, nasional, maupun internasional. Termasuk juga bagaimana merubah budaya para pejabat publik yang minta dilayani, bukan melayani masyarakat, seperti dikemukakan J.S. Mill, bahwa esensi dan arti birokrasi adalah pekerjaan menjalankan pemerintahan oleh orang-orang yang memerintah secara profesional (Albrow, 2005: 8).

Perbaikan birokrasi negara tidak bisa dijalankan secara parsial. Seringkali kegagalan birokrasi dalam menjalankan fungsinya justru disebabkan oleh faktor internal. Kurangnya integritas pimpinan serta kurangnya profesionalitas jajaran birokrasi dalam menjalankan tugasnya dan lemahnya peraturan perundang-undangan mengenai akuntabilitas birokrasi masih menjadi hambatan utama. Maraknya praktek KKN merupakan isu sentral yang menyebabkan rendahnya kinerja birokrasi. Bahkan, perbaikan hukum dan peradilan juga belum dapat diandalkan sebagai strategi pemulihan kepercayaan publik dan pihak luar terhadap birokrasi Indonesia.

Hasil survei yang dilakukan oleh Transparansi Internasional Indonesia menemukan fakta bahwa indeks persepsi korupsi Indonesia meningkat dari 2,0 pada 2005 menjadi 2,6 pada tahun 2008 dan bahkan pada tahun 2010 semakin meningkat menjadi 2,8 . Survei itu juga menyimpulkan bahwa lembaga yang bersifat hirarkis dan mengurus penegakan hukum, yakni kepolisian dan peradilan, justru paling bermasalah dan menghambat pemberantasan korupsi (Siaran
Pers TI Indonesia, 2009). Desentralisasi kewenangan pemerintahan ke daerah seakan disertai juga dengan desentralisasi perilaku korupsi. Pemindahan korupsi ke daerah terlihat jelas dengan banyaknya kasus korupsi para pejabat politis maupun pejabat birokrasi yang diungkap oleh KPK, bahkan hingga melibatkan pejabat pemerintahan desa. Data KPK tahun 2008 menunjukkan bahwa $70 \%$ kasus korupsi yang ditangani merupakan kasus korupsi di daerah (Kristant, 2009).

Pemerintah pada dasarnya telah memberikan komitmen yang cukup serius bagi upaya pemberantasan tindak pidana korupsi, ditandai dengan dikeluarkannya beberapa regulasi yang memberi legitimasi bagi langkah dan gerakan pemberantasan korupsi. Setidaknya tiga undangundang telah dibentuk untuk mendukung gerakan ini, UU No. 31 Tahun 1999 tentang Pemberantasan Tindak Pidana Korupsi, yang selanjutnya diamandemen menjadi UU No. 20 Tahun 2001, UU No. 30 Tahun 2002 tentang Komisi Pemberantasan Tindak Pidana Korupsi, dan UU No. 46 Tahun 2009 tentang Pengadilan Tindak Pidana Korupsi. Selain itu, penegakan hukumnya juga mulai memperlihatkan hasil, terbukti dengan mulai dikuaknya beberapa kasus kakap korupsi dan serangkain kasus lainnya yang berhasil mengungkap perilaku korup para pejabat publik dari berbagai sektor, golongan dan tingkatan. Artinya, political will dari negara terhadap upaya pemberantasan tindak pidana korupsi, sedikit banyak telah memenuhi harapan masyarakat. Meskipun kekurangan dan kelemahan juga masih bermunculan di beragam sisi, seperti seringkalinya tebang pilih dalam penuntasan kasus korupsi, dan upaya "memberikan perlindungan" atau paling tidak menunda pengusutan kasus-kasus korupsi yang diduga dilakukan oleh orang-orang dekat penguasa.

Kendati begitu, seperti telah dipaparkan di atas, sekedar upaya penciptaan regulasi dan penegakan hukum tentu tak cukup untuk membabat habis korupsi. Perlu perubahan paradigma para aparat negara, dalam penyelenggaraan pemerintahan birokrasi maupun masyarakat. Dalam konteks ini, dibutuhkan perubahan orientasi birokrasi dengan membebaskan dirinya dari yang berorientasi pada pelayanan terhadap kekuasaan maupun pelayan bagi dirinya sendiri. Struktur dilematis yang membuat birokrasi terjebak pada kepentingan kekuasaan atau yang cenderung diukur melalui ukuran-ukuran politis harus diubah menjadi kategori lain di wilayah pelayanan publik. Ukuranukuran keberhasilan kinerja birokrasi yang melulu hanya diukur melalui ketepatan prosedural harus dikembangkan ke arah ukuran-ukuran yang berorientasi keluar (pelayanan publik). Pembebasan dari struktur dilemetis ini dengan 
demikian adalah langkah ganda antara deorientasi dan reorientasi sekaligus dari birokrasi dengan mempertimbangkan faktor lingkungannya.

Posisi birokrasi justru akan bertambah solid jika mampu menempatkan posisinya sebagai partner bagi masyarakat. Sebagai partner, birokrasi dapat menjadi pihak yang sensitif dan responsif terhadap perubahan dalam masyarakat ini, sehingga aspek pelayanan dalam arti yang berorientasi pada tuntutan kebutuhan yang diinginkan publik ini dapat dilakukan. Namun demikian, sebagai partner, dalam beberapa kasus tidak dapat dipungkiri posisi birokrasi tetap menjadi dominan. Di sinilah makna penting dari konseptualisasi Fukuyama dalam hal mereposisi negara (termasuk di dalamnya birokrasi). Dalam bukunya State Building, Fukuyama menekankan pentingnya konseptualisasi ulang terhadap posisi dan peran negara melalui dua konsep utama, yaitu skope (scope) dan kapasitas (capacity) dari negara (Fukuyama, 2004).

Fukuyama menjelaskan relasi antara (scope) dan kapasitas (capacity) akan menempatkan suatu negara dalam salah satu dari empat kuadran seperti pada gambar 1. Negara yang kuat atau bisa dikatakan sukses adalah negara yang memiliki kapasitas yang kuat, baik dengan fungsi yang banyak maupun sedikit. Namun perlu penekanan bahwa kapasitas negara adalah sejauh mana negara mampu menjalankan fungsinya dengan baik. Kapasitas negara kuat tidak harus selalu dalam artian mengatur secara luas tetapi lebih kepada kualitas dan kapasitas negara pada yang menghasilkan kesejahteraan bagi masyarakatnya. Jika kita menarik tesisnya Fukuyama ini kedalam situasi negara Indonesia saat ini mungkin dapat dilihat dari peran negara melalui birokrasi yang sangat dominan, perlu kiranya untuk melakukan reposisi diri birokrasi itu sendiri. Bagaimana keberadaan birokrasi lebih efektif dan efesien dalam memberikan layanan

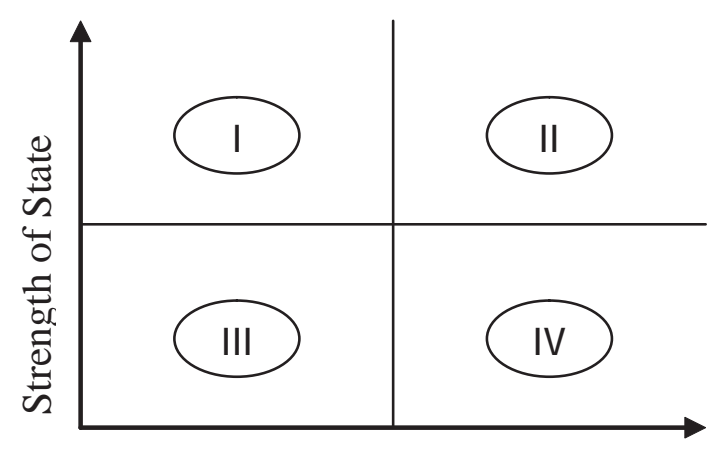

Scope of State Functions

Gambar 1: Reposisi dan Peran Negara Menurut Fukuyama State-Building: Governance and World Order in the 21st Century, 2004 pada masyarakat dengan tujuan mempermudah. Dalam konteks struktur dilematis yang mengkerangkai eksistensi birokrasi selama ini, pelibatan aktor-aktor masyarakat, dengan demikian menjadi kunci penting bagi upaya pembebasan birokrasi dari keterjebakannya berkutat dalam internal negara (baik dalam konteks hubungannya dengan politisi maupun dari jebakan otonomi dirinya). Pelibatan aktor-aktor masyarakat di luar diri birokrasi dengan demikian memungkinkan birokrasi bersikap sensitif dan mampu bertidak responsif terhadap lingkungannya. Wilayah pelibatan sendiri dapat dilakukan dengan mencakup daur siklus kebijakan, yang mencakup tahapan perencanaan, mobilisasi sumber daya, maupun pelaksanaan kebijakan. Pada wilayah ini, aktoraktor masyarakat dapat mewujudkan diri sekaligus sebagai pengawas birokrasi untuk menghindari penyimpangan (korupsi). Kemampuan dan kesadaran masyarakat menjadi persyaratan penting bagi peran ini.

\section{Pengalaman Kearifan Lokal dalam Memberantas Korupsi di Nagari}

Dalam kerangka pelibatan aktor-aktor masyarakat di luar diri birokrasi bagi upaya pendukung reformasi dirinya, bagian ini melihat bahwa nilai-nilai dalam masyarakat menjadi sangat penting. Kesadaran publik (masyarakat) akan peran penting mereka sebagai pengontrol birokrasi yang akan disoroti dari kasus yang terjadi di nagari Kapau. Peran dari nilai-nilai yang tumbuh dalam masyarakat dapat menjadi kekuatan yang mampu mendorong pemberantasan korupsi di birokrasi pemerintah.

Kebijakan desentralisasi yang digulirkan semenjak awal era reformasi memberi ruang yang besar bagi daerah untuk secara mandiri dalam penyelenggaraan pemerintahan dan lebih bebas dari kekuasaan pusat. Namun Pada kenyataannya Negara masih terlampau jauh masuk dalam wilayah lokal, dengan membuat aturan formal disertai dengan dasar hukum yang mengikat yang ditujukan kepada perangkat pemerintahan lokal. Pemberian otonomi kepada daerah untuk membentuk karakter pemerintahan sendiri sesuai dengan konsep lokal, menjadi lebih hanya sebagai kebijakan untuk menyenangkan hati daerah. Kenyataannya pengaturan yang ketat dari pusat masih saja menjadi hal yang harus dipenuhi oleh daerah. Sehingga pemerintahan lokal tidak lebih sebagai lembaga pemerintahan yang menjalankan adminstrasi pemerintahan di daerah.

Konsep pemerintahan terendah seperti Nagari yang dikembangkan di Sumatera Barat seperti kehilangan makna, ketika Negara masuk ke Nagari dengan seperangkat aturan yang menciptakan Nagari menjadi terjebak sebagai perangkat birokrasi. Dalam konteks ini Nagari 
menjadi lahan yang subur bagi praktik korupsi, apalagi dengan adanya anggaran dana alokasi umum nagari (DAUN) berkisar Rp 100 - Rp 150 juta yang berasal dari APDB dikucurkan pada masing-masing Nagari. Penggunaan anggaran nagari ini diserahkan kepada Pemerintahan Nagari. Ketiadaan lembaga hukum di tingkat nagari membuat birokrasi Nagari dapat melakukan apapun tanpa adanya pengawasan.

Perilaku korupsi yang memang sudah mengakar di level birokrasi pusat dan daerah, juga memperlihatkan wajah yang sama pada level birokrasi Nagari sebagai pemerintahan terendah. Ketiadaan lembaga penegak hukum di tingkat pemerintahan nagari, menjadikan Wali Nagari sebagai pemegang kekuasaan pemerintahan sekaligus birokrasi nagari menjadi dominan. Peluang wali nagari untuk bertindak dan membuat kebijakan yang memiliki indikasi korupsi sangat besar. Birokrasi Nagari yang di isi oleh orang-orang yang kurang memiliki kompetensi yang baik membuat birokrasi nagari sangat tergantung kepada wali nagari.

Model struktur kelembagaan Nagari seperti pada gambar diatas sangat jelas posisi wali nagari memiliki otoritas yang besar dalam mengatur penggunaan anggaran DAUN. Posisi kewenangan Wali Nagari yang sangat besar terhadap struktur birokrasi dibawahnya dan hubungan langsung dengan Bupati, memberikan keleluasaan Wali Nagari untuk membuat kebijakan dengan menggunakan kekuasaan diskresi yang didapat dari pelimpahan kewenangan oleh Bupati. Dalam menjalankan kekuasaan diskresi mungkin saja seorang pejabat tidak menikmati hasilnya tetapi dapat saja yang menikmatinya adalah pihak lain yang selama ini mendukung posisinya yang

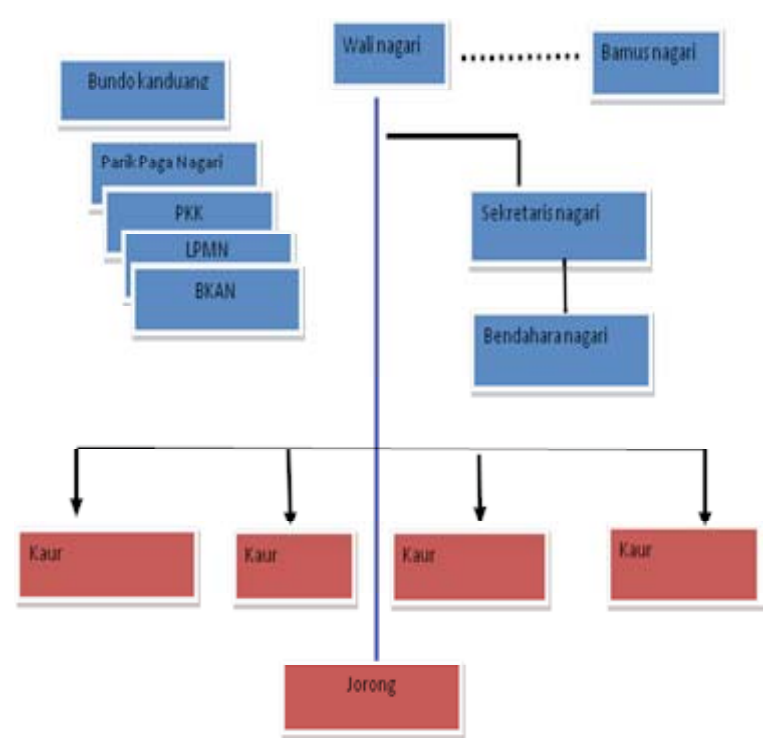

Gambar 2: Struktur Pemerintahan Nagari dampak dari perbuatanya yang dapat merugikan Negara (Benny I rawan, 2012:148). Pada kondisi ini, semestinya Nagari mempunyai lembaga yang dapat mengontrol perilaku para pejabat birokrasi. Namun kenyataannya Nagari tidak memiliki lembaga seperti halnya KPK dan perangkat lembaga hukum lainnya. Berkaca dari kondisi pada kasus korupsi level pusat maupun kabupaten/kota yang telah memiliki perangkat pengontrol dan lembaga pemberantas korupsi yang lebih jelas, tetapi tetap saja korupsi menjadi sangat masif. Mungkin perilaku korupsi di Nagari dapat kita pahami dengan ketiadaan lembaga yang berfungsi mencegah dan memberantas korupsi.

Tetapi kasus di nagari Kapau Kabupaten Agam Sumatera Barat, memiliki pengalaman yang menarik untuk di kaji, ketika masyarakat Nagari dapat melakukan pemberantasan korupsi di birokrasi nagari tanpa memerlukan lembaga khusus yang berwenang dan lembaga hukum lainnya. Masyarakat nagari Kapau pada tahun 2010 berhasil mengungkap kasus korupsi yang dilakukan oleh Wali Nagari, yang berakhir dengan pemberhentian wali nagari.

Nagari Kapau memiliki struktur pemerintahan sama halnya dengan nagari-nagari lainnya di Sumatera Barat. Struktur pemerintahan yang dibentuk negara sebagai perangkat birokrasi memang terlihat jelas. Tetapi secara kultural nagari Kapau menganut sistem pemerintahan adat Koto Piliang yang lebih bersifat otokratis. Kepemimpinan adat di nagari Kapau dilaksanakan oleh ninik mamak VI suku yang disebut sebagai urek tunggang yakni Dt. Bandaro (rajo adat) suku J ambak Gadang, Dt. Mangkudun (rajo ibadat) suku Melayu, Dt. Indo Marajo (bendaharawan) suku Jambak Kacik, Dt. Palimo (keamanan) suku Koto, Dt Panduko Basa (pengairan) suku Tanjuang, Pisang dan Simabua, Dt. Tan Dilangik (sosial politik) suku Guci dan Pili. Urek tunggang ini bekerja sebagai pelaksana pemerintahan dan mengatur hubungan sosial dalam masyarakat. Kepemimpinan tertinggi dipegang oleh penghulu pucuak bulekyang merupakan pemimpin dari ninik mamak enam suku. Namun dalam struktur Nagari modern sekarang posisi urek tunggang sudah tidak jelas lagi kedudukan mereka. Tetapi model sistem pemerintahan adat Koto Piliang masih dipegang teguh oleh masyarakat Nagari Kapau. Kelembagaan adat yang terdiri dari ninik mamak dari enam suku memiliki penghulu pucuak bulek yakni seorang pemimpin tertinggi yang dipilih dari salah seorang ninik mamak tersebut. Dalam kepemimpinan pucuak bulek merupakan seorang pemegang kekuasaan paling tinggi dalam pengambilan keputusan. Model pengambilan keputusan yang "bajanjang naiak, batanggo turun", memperlihatkan bahwa kekuasaan tersusun pada strata-strata secara bertingkat dengan 
wewenangnya bersifat vertikal.

Masyarakat Nagari Kapau meskipun menganut sistem Koto Piliang yang otokratis, tetapi masyarakat tetap memegang prinsip musyawarah untuk pengambilan keputusan, "bulek aie dek pambuluah, bulek kati dek mufakat"menjadi prinsip yang dipegang daalam pembuatan kebijakan. Penghulu pucuak sebagai elemen otoritas adat tidak serta merta menjadi primus interprise dalam membuat keputusan, namun tetap didasarkan kepada kesepakatan dari ninik mamak VI suku sebagai representasi masyarakat Kapau.

Masyarakat Kapau memiliki perhatian dan partisipasi yang cukup tinggi terhadap penyelenggaraan pemerintahan Nagari, hal ini dibuktikan dengan hadirnya kontrol publik terhadap pemerintahan nagari. Tuntutan beberapa wakil masyarakat untuk keterbukaan informasi dari wali nagari periode 2006-2012 tentang penggunaan dana pembangunan jalan nagari dan dana goro badunsanak 2008 menjadi salah satu praktek nilai transparansi yang nyata di nagari Kapau (Surat pengaduan LPMN tentang tindakan Wali Nagari tanggal 27 Maret 2009 kepada Bupati Agam). Wali Nagari sebagai pemimpin di nagari tidak dapat sewenang-wenang dalam melaksanakan pemerintahan karena ada kontrol publik terhadapnya, penilaian masyarakat terhadap kinerja Wali Nagari dan jajarannya menjadi indikator bagi keberhasilan seorang pemimpin. Penilaian kinerja yang jelek oleh publik terhadap wali nagari Kapau periode 2006-2012 menjadi salah satu poin pengaduan warga kepada Badan
Musyawarah (BAMUS) Nagari. Keberadaan ninik mamak VI suku menjadi jembatan bagi masyarakat yang menuntut pengusutan indikasi kasus korupsi tersebut.

Surat masyarakat Nagari Kapau (yang diwakili oleh para ninik mamak suku) pada tanggal 2 desember 2008 kepada Bamus nagari Kapau sebagai perwakilan legislatifnya nagari yang berisikan pernyataan pengaduan: (1) Pengakuan wali nagari Kapau di hadapan ikatan perantau keluarga Kapau di Jakarta - Bandung pada bulan Mei yang menggatakan bahwa wali nagari Kapau dan ninik mamak VI suku menerima uang fee (pitih cindua) dari hasil penjualan tanah nagari Kapau di Pandan Banyak untuk keperluan pasar ternak kota Bukittingi yang jelas telah melanggar UU adat nagari Kapau tahun 1955. (2) Sikap nagari Kapau yang tidak perduli terhadap kelancaran pelaksanaan pekerjaan di nagari. (3) Wali Nagari Kapau menutupi kepada masyarakat Kapau laporan pelaksanaan pekerjaan pembangunan jalan menuju rumah wali nagari Kapau di jorong Ladang Laweh yang menelan dana ratusan juta rupiah yang berasal dari dana bantuan nagari Kapau dan APBD kabupaten. Surat ini menuntut Bamus untuk mengusut kasus Wali Nagari tersebut.

Bamus selaku perwakilan masyarakat nagari menindaklanjuti pengaduan masyarakat. Desakan dari para ninik mamak yang berada diluar Bamus untuk menyelesaikan kasus korupsi ini, mendorong Bamus untuk memutuskan pengusulan pemberhentian Wali Nagari yang terbukti melakukan korupsi. Ketika publik sudah resah

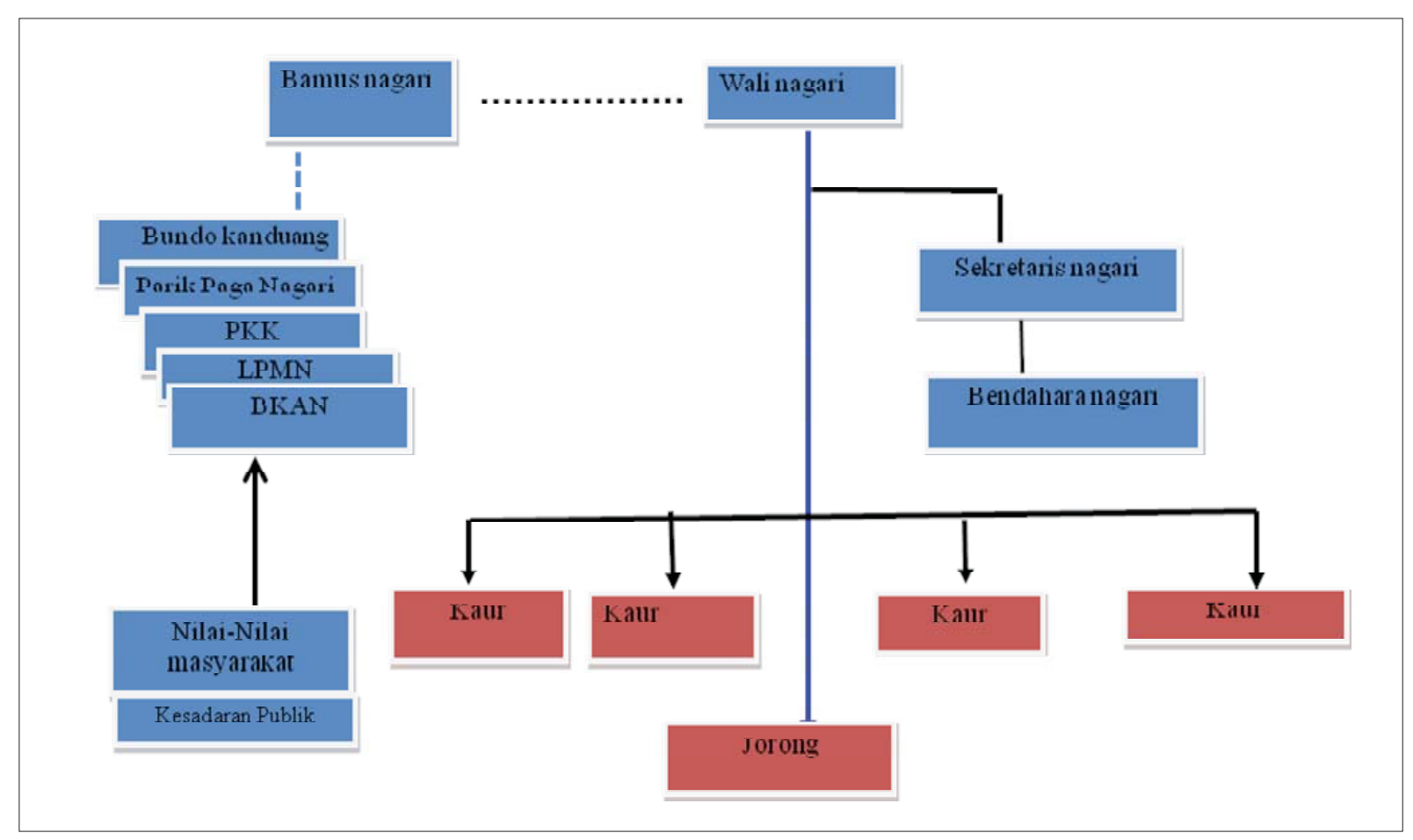

Gambar 3:

Hubungan kekuasaan dan peran masyarakat dalam pengawasan Pemerintahan Nagari Kapau 
dengan indikasi kasus korupsi Wali Nagari, peranan elit nagari dalam kelembagaan lain menjadi penting sebagai kekuatan yang mendorong penyelesaian kasus korupsi tersebut.

Kemudian tokoh masyarakat lain yang menjabat sebagai ketua LPMN Kapau, Fakhrizal yang memberikan surat pengaduan kepada Bupati Agam pada tanggal 27 Maret 2009 bahwa: (1) wali nagari Kapau periode 2006-2012 telah melakukan pengggelapan dana Negara dan dana goro budansanak arahan bupati Agam tahun 2008. (2) Laporan SPJ keuangan yang telah dikirim ke Bupati Agam dengan tembusan dinas sosial merupakan hasil rekayasa dari wali nagari Kapau dan kenyataannya tidak sesuai dengan kondisi fisik dilapangan. (3) Dalam pekerjaannya wali nagari tidak pernah berkoordinasi dengan LPMN Kapau yang semestinya dikelola dan dilaksanakan oleh LPMN Kapau. Surat pengaduan ketua LPMN ini memperkuat pengusulan Bamus kepada Bupati untuk pemberhentian Wali Nagari.

Kesadaran masyarakat akan pentingnya partisipasi mereka dalam mengawasi pemerintahan nagari menuntut adanya keterbukaan informasi oleh pejabat nagari. Ketika akses informasi tersumbat, hal ini akan dapat menjadi persoalan yang harus dipertangunggjawabkan pejabat wali nagari. Rendahnya akuntabilitas birokrasi publik Salah satu penyebab maraknya praktik korupsi di Indonesia (Kumorotomo, 2005:5).

Adanya pembagian kekuasan dan tupoksi yang jelas dari masing masing lembaga di nagari seperti pada gambar 3, Wali Nagari sebagai perangkat eksekutif harus bisa bekerja sama dengan Bamus sebagai lembaga legislatif. Sehingga pada prakteknya ketika wali nagari melakukan indikasi korupsi dana anggaran nagari, maka Bamus nagari Kapau siap memberikan mosi tidak percayanya pada wali nagari, terbukti melalui surat Bamus kepada Bupati Agam No. 050/Bamus/ KP-2009 tentang permohonan percepatan pemberhentian wali nagari Kapau periode 20062012 dan ditindak lanjuti dengan surat Camat Tilatang Kamang ke Bupati Agam dengan No 100/ 96/pem/XI-2009 tentang pengusulan pemberhentian wali nagari Kapau (Edi Gusrianto, S.Pdi) sebagai wali nagari Kapau.

Belajar dari kasus pemberantasan kasus korupsi di nagari Kapau ini, ada beberapa hal yang perlu dicatat sebagai potensi cara dalam memberantas korupsi. Pertama nagari memiliki nilai-nilai kultural yang mampu menciptakan struktur masyarakat dan kekuasaan yang menjadi kekuatan untuk dapat mengontrol kerja birokrasi Pemerintah Nagari formal yang dibentuk oleh aturan negara. Dalam kerangka ini, nilai dan lembaga tradisional merupakan kekuatan yang potensial sebagai instrumen pencegah tindakan korupsi yang memang sangat kental dengan birokrasi Indonesia. Namun nilai-nilai kultural ini tidak dapat digunakan jika pemerintahan tidak memiliki orientasi perubahan paradigma yang memperhatikan lingkungan. Kedua partisipasi merupakan kata kunci utama bagi wali nagari dan perangkat adat serta perangkat pemerintahan untuk membangun konsep kesadaran publik dalam penyelenggaraan pemerintahan (birokrasi). Setiap warga atau elemen-elemen masyarakat mempunyai kesempatan dan hak untuk melakukan pengawasan (kontrol) terhadap jalannya pemerintahan maupun pengelolaan kebijakan dan keuangan pemerintah.

Ketiga peranan kesadaran publik dalam mengontrol kerja birokrasi bisa menjadi efektif meskipun tanpa adanya lembaga hukum secara formal. Potensi besar indikasi korupsi tersebut ternyata bisa dihapus dengan mengukuhkan kembali makna integritas anti korupsi (Pope, 2007) di lembaga pada tingkatan lokal yang selama ini hanya menjadi tambo dan budaya yang dibaca saja tanpa dipahami lebih lanjut makna yang tersirat didalammnya.

Pengalaman nagari Kapau dalam memberantas korupsi membutuhkan persyaratan yang berasal dari dalan birokrasi itu sendiri. Pertama keterbukaan akses publik terhadap informasi birokrasi menjadi penting untuk meningkatkan efektivitas pengawasan publik. Kedua kemauan birokrasi sendiri dalam mengintegrasikan nilai-nilai masyarakat kedalam budaya birokrasi itu dengan mengurangi resistensi terhadap perubahan. Persyaratan ini membutuhkan pelembagaan yang baik dalam diri birokrasi. Pelembagaan menjamin terjadinya kepastian keberlanjutan sekaligus upaya reformasi terus-menerus bagi pencapaian tujuan. Pelembagaan di sini bukan hal yang mudah. Setiap upaya perubahan ini sangat mungkin tidak direspon secara positif oleh semua komponen dalam diri birokrasi. Padahal, setiap perubahan semestinya merupakan sebuah keputusan kolektif yang diterima oleh semua pihak. Dalam konteks ini, Kurt Lewin menyatakan bahwa kekuatan tekanan (driving forces) untuk mendesakkan perubahan akan berhadapan dengan penolakan (resistences) untuk berubah. Menurutnya, untuk mengatasi kondisi ini, yang bisa dilakukan adalah dengan memperkuat driving forces dan melemahkan resistences to change di sisi yang lain (Lewin dalam Kasali, 2005).

Dalam konteks pelembagaan ini, Fukuyama mencatat empat komponen utama dalam penguatan kapasitas kelembagaan berikut derajat transferability-nya dalam melakukan pelembagaan perubahan dalam setiap organisasi. Berikut adalah empat komponen yang diajukan oleh Fukuyama seperti pada Tabel 1. 


\section{Tabel 1 Components of I nstitutional Capacity}

\begin{tabular}{|ll|}
\hline Component & Transferability \\
\hline $\begin{array}{l}\text { Organizational design } \\
\text { and management }\end{array}$ & High \\
Institutional design & Medium \\
Basis of legitimation & Medium-Low \\
Social and Cultural factors & Low \\
\hline
\end{tabular}

Keempat komponen tersebut menunjukkan adanya perbedaan tingkat kecepatan dari masingmasing komponen untuk dapat dilembagakan. Faktor internal yang terbatas pada penataan tata kelola organisasi terbilang paling cepat bisa dilaksanakan dan akan semakin melambat ketika berkenaan dengan upaya untuk melembagakan desain kelembagaan dari birokrasi agar mampu mencapai hasil-hasil yang koheren dengan pencapaian misi dari birokrasi (outcome).

Sedangkan aspek kekuasaan yang menjadi basis legitimasi dari birokrasi terbilang lebih susah dan cenderung akan terjebak sangat sulit. Dalam konteks birokrasi, ini dapat dilihat dalam konteks hubungan antara birokrasi dan kekuasaan, termasuk di dalamnya adalah politisi. Sedangkan faktor eksternal yang paling sulit adalah bagaimana melembagakan faktor-faktor sosio-kultural yang ada dalam masyarakat agar sinergis dengan pencapaian tujuan birokrasi. Dalam kerangka ini, birokrasi memang perlu didorong untuk dapat mempercepat perubahan pelembagaan sosiokultural dengan driven dari publik itu sendiri.

\section{Simpulan dan Saran}

Pemberantasan korupsi tidak melulu merupakan tanggungjawab pemerintah dengan pendekatan struktural formal. Kerjasama antara lingkungan intern birokrasi dengan lingkungannya menjadi suatui keniscayaan bagi upaya birokrasi untuk mereformasi diri. Keterlibatan lingkungan birokrasi sangat mungkin membantu driven pemberantasan korupsi terutama dengan mengintegrasikan nilai-nilai budaya yang potensial dalam penyelenggaraan birokrasi. Meskipun melembagakan faktor-faktor sosio-kultural kedalam birokrasi adalah faktor yang paling sulit menurut Fukuyama, tetapi elemen ini sangat potensial bagi sarana mendorong perubahan dalam birokrasi.

Keberhasilan masyarakat Nagari Kapau untuk dapat mendesakkan perubahan ini pada birokrasi Nagari dapat menjadi model yang dapat dikembangkan dalam lingkungan masyarakat dan birokrasi manapun. Kesedian birokrasi untuk terbuka dan kesadaran dari publik akan tanggungjawab mereka sebagai bahagian dari sistem menjadi sayarat penting keberhasilan perubahan. Eksplorasi nilai dan elemen masyarakat yang dapat mendorong berkembangnya struktur masyarakat dan birokrasi yang terbuka perlu untuk terus dieks/porasi. Dengan demikian, masih ada banyak harapan dalam reformasi birokrasi sebagai cara untuk memperbaiki budaya dan perilaku birokrat.

\section{Daftar Pustaka}

Albrow, M. (2005).Birokrasi (terj), Yogyakarta. Tiara Wacana.

Djafar, W. (2006) Memotong Warisan Birokrasi Masa lalu, menciptakan Demarkasi Bebas korupsi. (https://wahyudidjafar.files. wordpress.com/2011/08/memotong-warisanbirokrasi-masa-lalu.pdf). diunduh pada 7 April 2012.

Etziony, Eva and Halevy, (1983). Bureaucracy and Democracy: A Political Dilemma, Revised Edition, Routledge \& Kegan Paul.

Fukuyama, F. (2004). State-Building: Governance and World Order in the 21st Century, New York: Cornell University Press.

Hadiz, Vedi R. dan Dhakidae(ed), (2006). I Imu Sosial dan Kekuasaan di Indonesia, Jakarta: Equinox Publishing.

I rawan, B. (2012), "Diskresi sebagai Tindak Pidana Korupsi: Kajian Kriminologi dan Hukum terhadap Fenomena Pejabat Otoritas", J urnal MIMBAR, Vol. XXVII, No. 2 (Desember 2011): 143-149 Terakreditasi' SK Dikti No. 64a/DI KTI/ Kep/2010.

Jackson, K. D. (1978). "Bureaucratic Polity: A Theoritical Framework for The Analysis of Power and Communications in Indonesia", in Political Power and Communications in Indonesia, Lucian W. Pye (ed). Berkley: University of California Press.

Junus, G. A. (2002). "Bukan Persoalan Telur dan Ayam: Membangun Suatu Kerangka Analisis yang Lebih Holistik bagi Gerakan Anti Korupsi di Indonesia", Jurnal Wacana Edisi 14 Tahun III 2002, Yogyakarta: Insisit Press.

Kasali, R. (2005). Change: Manajemen Perubahan dan Manajemen Harapan, Jakarta: Gramedia Pustaka Utama.

Kumorotomo, W. (2005). Akuntabilitas Birokrasi Publik, Yogyakarta: Pustaka Pelajar.

Mac, R.M.I . (1977). Negara Modern (terj), J akarta: Aksara Baru. 
Muhaimin, Y. (1980). "Beberapa Segi Birokrasi di Indonesia", Jurnal Prisma No.10 Tahun IX Oktober 1980.

Pope, J. (2007), Strategi Memberantas Korupsi (Elemen Sistem Integritas Nasional). J akarata: Transparansi Internasional Indonesia dan Yayasan Obor Indonesia.

Robison, R., and Hadiz, V.R. (2004). Reorganizing Power in Indonesia: The Politics of Oligarchy in an Age of Markets, London: Routledge.

Semma, M. (2008). Negara dan Korupsi: Pemikiran Mochtar Lubis atas Negara, Manusia Indone- sia, dan Perilaku Politik, J akarta: Yayasan Obor Indonesia.

Wibowo, S.R. (2009), Indeks Persepsi Korupsi Indonesia 2008, Siaran Pers Transparansi Internasional Indonesia, http:// www.ipkindonesia.org/press-release/2009/ 01/21/indeks-persepsi-korupsi-indonesia2008, di akses 9 Mei 2012.

Yunita, E.K. (2009). Pejabat Daerah Pelaku Korupsi Terbanyak, selasa, (http://korupsi. vivanews.com/news/read/ 19933pejabat_daerah_pelaku_korupsi_ terbanyak). diunduh 9 Mei 2012. 